\title{
PENGKAYAAN Daphnia spp. DENGAN VITERNA TERHADAP KELANGSUNGAN HIDUP DAN PERTUMBUHAN LARVA IKAN LELE DUMBO (Clarias gariepinus)
}

\section{ENRICHMENT of Daphnia spp. with VITERNA to SURVIVAL and GROWTH of AFRICAN CATFISH (Clarias gariepinus) LARVAE}

\author{
Naila Budiatin Wahyu Mufidah, Boedi Setya Rahardja dan Woro Hastuti Satyantini \\ Fakultas Perikanan dan Kelautan Universitas Airlangga \\ Kampus C Mulyorejo - Surabaya 60115 Telp. 031-5911451
}

\begin{abstract}
African catfish (Clarias gariepinus) is one of fish consumption use to fulfill animal protein. The fulfillment need of animal protein with aquaculture effort, where as in the aquaculture effort will larvae quality increased. Increasingly of larvae quality with natural food had been adding feed supplement. Natural food to used is Daphnia spp. and then food supplement to used is viterna. The viterna will increase Daphnia nutritions, because of the viterna contains many nutritions to survival and growth of African catfish.

The aim of this study was to know the influence of Daphnia spp. enrichment with viterna to survival and growth of African catfish (Clarias gariepinus) larvae. The rearing of larvae during 40 days. This study used Complete Random Design. The treatment were A (present Daphnia spp. without viterna), B (Daphnia spp. enrichment with viterna $10 \mathrm{ml} / \mathrm{L}$ dose), C (Daphnia spp. enrichment with viterna 10 $\mathrm{ml} / \mathrm{L}$ dose), D (Daphnia spp. enrichment with viterna $10 \mathrm{ml} / \mathrm{L}$ dose), E (Daphnia spp. enrichment with viterna $10 \mathrm{ml} / \mathrm{L}$ dose) dan F (Daphnia spp. enrichment with viterna $10 \mathrm{ml} / \mathrm{L}$ dose), each treatment with 4 replications.

The result show that viterna applications to Daphnia was significantly influenced $(\mathrm{p}<0,05)$ to survival African catfish larvae. The highest survival was E treatment $(7,25 \%)$. The viterna leaf to Daphnia spp. Was significantly influenced $(\mathrm{p}<0,05)$ to specific growth rate African catfish larvae. The highest specific growth rate was $\mathrm{B}$ treatment $(1,885 \% \mathrm{BW} /$ day $)$.
\end{abstract}

Key words : African catfish, viterna, survival and growth.

\section{Pendahuluan}

Salah satu kendala dalam budidaya ikan lele dumbo adalah ketersediaan benih kurang mencukupi kebutuhan pembudidaya. Oleh sebab itu, teknik pemeliharaan dalam usaha budidaya ikan lele dumbo perlu dikembangkan. Salah satu cara pengembangan budidaya yaitu penambahan nutrisi pakan alami larva ikan lele dengan cara pengkayaan. Pakan alami yang digunakan adalah Daphnia, sedangkan pengkayaan menggunakan viterna yang merupakan suplemen yang berasal dari berbagai macam bahan alami yang bermanfaat untuk meningkatkan kandungan nutrisi dan mempercepat pertumbuhan (Wisnu, 2007).

Penggunaan Daphnia sebagai pakan alami larva ikan lele dumbo karena mempunyai ukuran yang kecil berkisar antara 0,2-5 mm (Wikipedia, 2007) yang sesuai untuk larva yang bersifat karnivora. Pengkayaan tersebut bertujuan untuk menambah nutrisi Daphnia yang diharapkan dapat mempengaruhi kelangsungan hidup dan pertumbuhan larva. Nilai nutrisi yang terkandung dalam Daphnia berat basah adalah $4 \%$ protein (Schumann, 2006), 0,54\% lemak dan 0,67\% karbohidrat (Wahyu, 2007). Sedangkan, nutrisi viterna adalah 42,82 \% protein, 47,31\% karbohidrat, $4,5 \%$ lemak, 2,74 \% mineral dan 2,63\% vitamin (Fauzan, 2004).

Daphnia mempunyai sifat non-selective filter feeder yaitu menyaring semua makanan yang ada tanpa memilih, sehingga viterna yang telah diberikan dalam media pemeliharaannya akan dimakan atau diserap oleh Daphnia. Selanjutnya, Daphnia yang telah diperkaya dengan viterna akan dimakan oleh larva. Daphnia yng ditambah nilia nutrisinya, sehingga diharapkan dapat memenuhi kebutuhan nutrisi larva lele, sehingga kelangsungan hidup dan pertumbuhannya baik.

Tujuan dari penelitian ini adalah untuk mengetahui pengaruh pengkayaan Daphnia dengan viterna dan mengetahui dosis pengkayaan viterna terhadap Daphnia untuk kelangsungan hidup dan pertumbuhan larva ikan lele dumbo. Penelitian ini diharapkan dapat memberikan informasi mengenai pemberian 
dosis pengkayaan viterna terhadap Daphnia yang digunakan untuk meningkatkan pertumbuhan dan tingkat kelangsungan hidup larva ikan lele dumbo dalam waktu pemeliharaan yang pendek

\section{Materi dan Metode Penelitian}

Penelitian ini telah dilaksanakan pada tanggal 24 Maret - 30 April 2008 di Laboratorium Pendidikan Perikanan, Fakultas Perikanan dan Kelautan, Universitas Airlangga. Alat yang digunakan adalah botol dengan diameter $\pm 8 \mathrm{~cm}$ dan tinggi $28 \mathrm{~cm}$, aerator dan selang aerator, gelas beker $50 \mathrm{ml}$, pipet, bak plastik sebanyak 24 buah, batu aerasi, seser dan timbangan, $\mathrm{pH}$ universal, termometer, amonia test kit dan DO test kit. Bahan yang digunakan adalah Daphnia spp., viterna dan larva ikan lele dumbo (Clarias gariepinus).

Penelitian pendahuluan dilakukan dengan tujuan untuk mengetahui waktu yang efektif dan kisaran dosis untuk penelitian utama. Wisnu (2007) menyatakan, dosis viterna untuk pertumbuhan ikan sebanyak $12,5 \mathrm{ml}$ yang dilarutkan dalam $250 \mathrm{ml}$ air, kemudian dicampur pakan buatan (pellet) sebanyak $2-3 \mathrm{~kg}$ pakan. Pakan tersebut diberikan terhadap ikan lele, gurami dan nila. Pemberian pakan buatan (pellet) yang telah dicampur dengan viterna bertujuan untuk menggemukan ikan, daging ikan menjadi padat dan pertumbuhan ikan sangat cepat serta ekonomis.

Penelitian pendahuluan menggunakan viterna dengan beberapa dosis yaitu $10 \mathrm{ml} / \mathrm{L}$ air, $50 \mathrm{ml} / \mathrm{L}$ air, $100 \mathrm{ml} / \mathrm{L}$ air, $200 \mathrm{ml} / \mathrm{L}$ air dan kontrol (tanpa penambahan viterna) dan lama pengkayaan 2 jam, 4 jam, 6 jam, 8 jam, 10 jam dan 12 jam. Viterna tersebut dimasukan dalam media pemeliharaan terlebih dahulu agar tercampur merata dengan air sebagai media pemeliharaan Daphnia. Selanjutnya, Daphnia dimasukkan ke dalam media pemeliharaan dengan populasi berkisar antara 500 ekor/L air. Selanjutnya, dilakukan pengamatan setiap 2 jam sekali. Pengamatan menggunakan mikroskop dengan pembesaran 100 kali. Hasil dari penelitian pendahuluan didapatkan, pada 4 jam pengkayaan hasil yang diperoleh adalah usus Daphnia terisi penuh viterna dengan populasi Daphnia yang meningkat terutama pada dosis $10 \mathrm{ml}$ dan $50 \mathrm{ml}$. Isi usus Daphnia spp. pada jam keempat dapat dilihat pada Gambar 1.

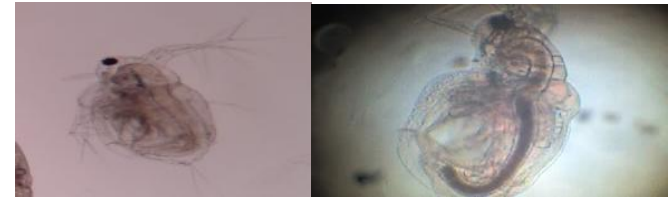

Gambar 1. Isi usus Daphnia spp. sebelum dan sesudah pengkayaan

Kualitas air pada pendahuluan adalah 7,5 (pH) dan suhu berkisar antara $23,5-25{ }^{\circ} \mathrm{C}$. Penurunan suhu terjadi pada malam hari, akan tetapi tidak mempengaruhi kelangsungan hidup Daphnia karena Daphnia dapat hidup pada kisaran suhu 17-24 ${ }^{\circ} \mathrm{C}$ (Lavens and Sorgeloos, 1996). Daphnia tumbuh pada pH 6,5-9,5 (Schumann, 2006).

Penelitian pendahuluan menghasilkan kisaran dosis pengkayaan viterna berkisar antara 10-50 $\mathrm{ml} / \mathrm{L}$ dengan lama waktu 4 jam, maka penelitian utama menggunakan 6 perlakuan dosis : Kontrol (pemberian Daphnia tanpa pengkaya), pengkayaan Daphnia dengan dosis $10 \mathrm{ml} / \mathrm{L}$ air, pengkayaan Daphnia dengan dosis $20 \mathrm{ml} / \mathrm{L}$ air, pengkayaan Daphnia dengan dosis $30 \mathrm{ml} / \mathrm{L}$ air, pengkayaan Daphnia dengan dosis $40 \mathrm{ml} / \mathrm{L}$ air, pengkayaan Daphnia dengan dosis $50 \mathrm{ml} / \mathrm{L}$ air. Setiap perlakuan tersebut dilakukan pengulangan sebanyak 4 kali ulangan dengan menggunakan Rancangan Acak Lengkap.

Pengkayaan Daphnia dilakukan dengan cara mempersiapkan air sebagai media pemeliharaan. Selanjutnya, viterna dengan dosis yang sesuai dengan hasil penelitian pendahuluan dimasukan ke dalam media pemeliharaan. Daphnia dengan kepadatan 500 ekor/L dimasukkan ke dalam media pengkayaan. Pengkayaan dilakukan selama 4 jam karena waktu tersebut merupakan waktu yang paling efektif dan efisien. Daphnia yang telah diperkaya selanjutnya diberikan terhadap larva ikan lele dumbo.

Langkah pertama dalam pemeliharaan larva ikan lele dumbo yaitu mempersiapkan bak pemeliharaan dan persiapan air sebagai media pemeliharaan larva dengan diaerasi terlebih dahulu untuk mengurangi kadar klorin dalam air PAM. Langkah selanjutnya, memasukkan larva ikan lele dumbo dengan kepadatan 100 ekor/L (Hecht dan Uys, 1997). Larva tersebut dipelihara selama 40 hari. Pemberian pakan pada larva lele dilakukan setelah Daphnia diperkaya dengan viterna sesuai dosis yang telah ditentukan. Pemberian Daphnia spp. yang telah ditambah nutrisinya dengan viterna diberikan terhadap larva ikan lele dumbo pada hari ketiga setelah menetas, dikarenakan pada hari ketiga kuning telur akan habis (Maya, 2006). Pakan alami berupa Daphnia spp. yang 
sudah diperkaya diberikan sebanyak $70 \%$ dari berat biomassa per hari (Sutanmuda, 2007). Pakan diberikan 2 kali sehari yaitu pada pagi dan sore hari (Khairuman dan Amri, 2002) yaitu pada pukul 09.00 dan 15.00. Hal tersebut dikarenakan, proses metabolisme dalam tubuh ikan membutuhkan waktu 6 jam untuk mencerna makanan.

Parameter utama dalam penelitian ini adalah kelangsungan hidup dan pertumbuhan larva. Kelangsungan hidup larva akan diketahui dengan menggunakan rumus (Mukti dkk., 2004)

SR (Kelangsungan hidup) = Jumlah burayak akhir perhitungan $\times 100 \%$ Jumlah burayak awal perhitungan

Pertumbuhan larva akan diketahui dengan melakukan pengukuran berat dengan menggunakan timbangan serta menggunakan rumus (Sahoo et. al., 2004) :

Laju pertumbuhan spesifik :

$\mathrm{SGR}=\underline{\ln \mathrm{Wt}-\ln \mathrm{W} 0} \times 100 \%$

keterangan :

SGR : Laju pertumbuhan spesifik (\%g/hari)

$\mathrm{W}_{\mathrm{t}}$ : Berat rata-rata tubuh ikan pada hari ke$\mathrm{t}(\mathrm{g})$

$\mathrm{W}_{0}$ : Berat rata-rata tubuh ikan pada awal pemeliharaan $(\mathrm{g})$

t : Waktu (hari)

Setiap 10 hari sekali dilakukan pengukuran berat tubuh larva untuk mengetahui laju pertumbuhan spesifik, sedangkan kelangsungan hidup diukur setelah 40 hari pemeliharaan.

Parameter pendukung yang digunakan meliputi kualitas air yaitu $\mathrm{pH}$, suhu, $\mathrm{NH}_{3}$ dan DO, masing-masing diukur dengan menggunakan $\mathrm{pH}$ universal, termometer, $\mathrm{NH}_{3}$ test kit dan DO test kit. Masing-masing pengukuran dilakukan setiap 1 minggu sekali.

Data yang diperoleh kemudian dianalisis menggunakan ANAVA (Analisis Varian) untuk mengetahui pengaruh dari semua perlakuan. Apabila terdapat perbedaan maka dilanjutkan dengan uji jarak berganda Duncan dengan derajat kepercayaan $5 \%$, untuk mengetahui perbedaan diantara perlakuan (Kusriningrum, 1989).

\section{Hasil dan Pembahasan}

Kelangsungan Hidup

Data persentase kelangsungan hidup larva ikan lele dumbo dianalisis dengan statistik. Berdasarkan hasil penghitungan statistik tersebut, rata-rata dan simpangan baku persentase kelangsungan hidup larva ikan lele dumbo (Clarias gariepinus) dapat dilihat pada Tabel 1 .

Tabel 1. Rata-rata dan simpangan baku persentase kelangsungan hidup larva ikan lele dumbo (Clarias gariepinus)

\begin{tabular}{|c|c|}
\hline Perlakuan & Rata-rata $(\%) \pm \mathrm{SD}$ \\
\hline A $($ kontrol $)$ & $56,875^{\mathrm{e}} \pm 0,4787$ \\
\hline $\mathrm{B}(10 \mathrm{ml} / \mathrm{L})$ & $63,375^{\mathrm{d}} \pm 0,6292$ \\
\hline $\mathrm{C}(20 \mathrm{ml} / \mathrm{L})$ & $66^{\mathrm{c}} \pm 1,2247$ \\
\hline $\mathrm{D}(30 \mathrm{ml} / \mathrm{L})$ & $67,375^{\mathrm{c}} \pm 1,1087$ \\
\hline $\mathrm{E}(40 \mathrm{ml} / \mathrm{L})$ & $72,5^{\mathrm{a}} \pm 0,9129$ \\
\hline $\mathrm{F}(50 \mathrm{ml} / \mathrm{L})$ & $69^{\mathrm{b}} \pm 1,0801$ \\
\hline
\end{tabular}

Keterangan: superskrip yang berbeda pada kolom yang sama menunjukan perbedaan nyata $(\mathrm{p}<0,05)$

Hasil penghitungan Anava tingkat kelangsungan hidup larva ikan lele dumbo yang diberi pakan Daphnia diperkaya dengan viterna menunjukkan hasil yang berbeda nyata $(\mathrm{p}<0,05)$. Selanjutnya, untuk mengetahui perlakuan mana yang memberikan hasil yang terbaik, maka dilakukan uji lanjutan dengan menggunakan Uji Jarak Berganda Duncan. Hasil dari uji jarak berganda Duncan menunjukkan bahwa pemberian Daphnia yang telah diperkaya dengan viterna menghasilkan tingkat kelangsungan hidup larva ikan lele dumbo terbaik pada perlakuan E $(72,5 \%)$ dan terendah pada perlakuan A $(59,5 \%)$. Perbandingan kelangsungan hidup pada tiap perlakuan selama 40 hari pemeliharaan dapat dilihat pada Gambar 2. 


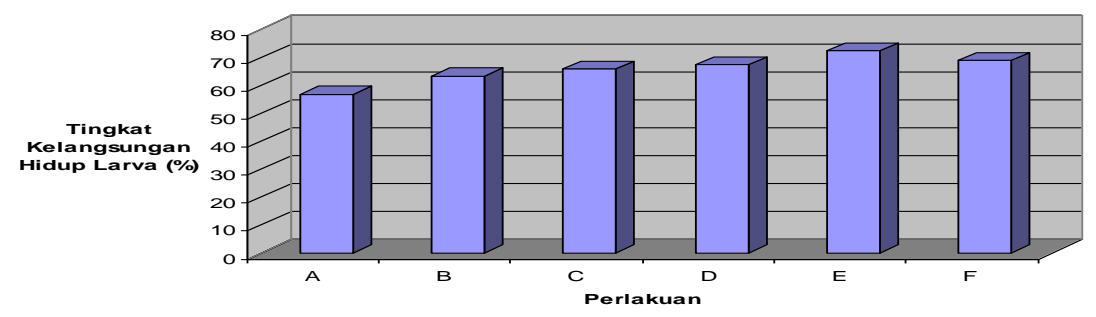

Gambar 2. Kelangsungan hidup larva lele setelah 40 hari pemeliharaan

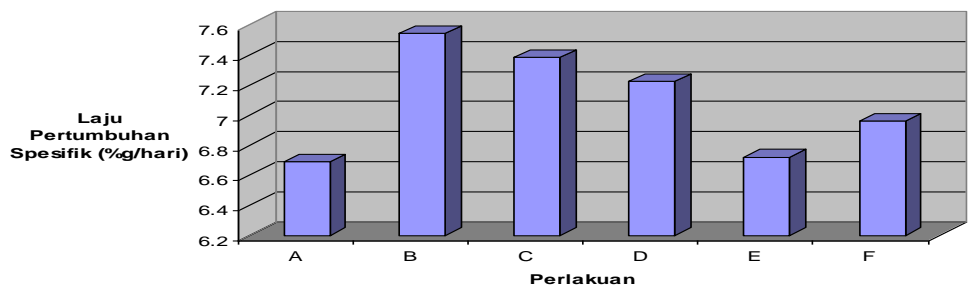

Gambar 4. Laju pertumbuhan spesifik hari pemeliharaan

Pertumbuhan larva lele dumbo

Pertumbuhan merupakan pertambahan berat tubuh ikan. Pertumbuhan larva lele dapat diketahui dengan menimbang berat tubuhnya. Dari berat rata-rata, selanjutnya digunakan untuk mengetahui laju pertumbuhan spesifik larva. Selanjutnya, data laju pertumbuhan spesifik larva ikan lele dumbo dihitung dengan penghitungan statistik. Berdasarkan hasil penghitungan statistik tersebut rata-rata dan simpangan baku laju pertumbuhan spesifik larva ikan lele dumbo (Clarias gariepinus) selama 40 hari pemeliharaan dapat dilihat pada Tabel 2.

Tabel 2. Rata-rata dan simpangan baku laju pertumbuhan spesifik larva ikan lele dumbo (Clarias gariepinus) selama 40 hari pemeliharaan

\begin{tabular}{|c|c|}
\hline Perlakuan & Rata-rata $(\% \mathrm{~g} /$ hari $) \pm \mathrm{SD}$ \\
\hline $\mathrm{A}($ kontrol$)$ & $1,673^{\mathrm{d}} \pm 0,015$ \\
\hline $\mathrm{B}(10 \mathrm{ml} / \mathrm{L})$ & $1,885^{\mathrm{a}} \pm 0,0545$ \\
\hline $\mathrm{C}(20 \mathrm{ml} / \mathrm{L})$ & $1,845^{\mathrm{b}} \pm 0,0551$ \\
\hline $\mathrm{D}(30 \mathrm{ml} / \mathrm{L})$ & $1,805^{\mathrm{b}} \pm 0,0507$ \\
\hline $\mathrm{E}(40 \mathrm{ml} / \mathrm{L})$ & $1,68^{\mathrm{c}} \pm 0,4243$ \\
\hline $\mathrm{F}(50 \mathrm{ml} / \mathrm{L})$ & $1,74^{\mathrm{c}} \pm 0,0356$ \\
\hline Keterangan : & $\begin{array}{l}\text { superskrip yang berbeda pada } \\
\text { kolom } \\
\end{array}$ \\
& $\begin{array}{l}\text { menunjukkan perbedaan nyata } \\
(\mathrm{p}<0,05)\end{array}$ \\
\hline
\end{tabular}

Hasil penghitungan Anava laju pertumbuhan spesifik larva ikan lele dumbo yang diberi pakan Daphnia diperkaya dengan viterna menugnjukkan hasil yang berbeda nyata $(\mathrm{p}<0,05)$. Selanjutnya, untuk mengetahui mana yang memberikan hasil yang terbaik, maka dilakukan uji lanjutan dengan menggunakan Uji Jarak Berganda Duncan. Hasil dari uji jarak berganda Duncan menunjukkan bahwa pemberian Daphnia yang telah diperkaya dengan viterna menghasilkan laju pertumbuhan spesifik larva ikan lele dumbo terbaik pada perlakuan B $(1,885 \% \mathrm{~g} / \mathrm{hari})$ dan terendah pada perlakuan A (1,673\%g/hari). Laju pertumbuhan larva lele pada tiap perlakuan selama pemeliharaan dapat dilihat pada Gambar 4.

Kualitas air

Parameter kualitas air yang diamati selama penelitian meliputi suhu, oksigen terlarut (DO), amonia $\left(\mathrm{NH}_{3}\right)$ dan derajat keasaman (pH). Pengukuran kualitas air dilakukan pada setiap perlakuan dan ulangan selama penelitian pada media pemeliharaan larva lele. Kualitas air pada media pemeliharaan larva lele di setiap perlakuan adalah suhu berkisar antara $28-29{ }^{\circ} \mathrm{C}$, $\mathrm{pH}$ 7,5-8, DO $6 \mathrm{mg} / \mathrm{L}$ dan $\mathrm{NH}_{3}$ berkisar antara 0,009-0,03 mg/L. Pada media pengkayaan Daphnia didapatkan data kualitas air sebagai berikut : suhu $24-25{ }^{\circ} \mathrm{C}$ dan $\mathrm{pH} 7,5$.

Kelangsungan hidup dipengaruhi oleh kualitas air, kebutuhan pakan, umur ikan dan lingkungan. Kualitas air yang diukur selama penelitian diusahakan berada pada kisaran yang sesuai dengan habitatnya, sedangkan kebutuhan 
pakan telah disediakan berupa pakan alami (Daphnia) yang sudah diperkaya dengan viterna. Faktor lain adalah umur ikan, dimana umur ikan berhubungan dengan pakan. Pada stadia larva merupakan tahapan yang paling kritis dalam siklus hidup ikan (Effendi, 2004), sehingga pakan harus tersedia secara terus menerus dan sesuai dengan kebutuhannya. Faktor lingkungan sekitar pemeliharaan juga mempengaruhi kelangsungan hidup larva lele. Lingkungan sekitar pemeliharaan selama penelitian terkontrol dengan baik.

Kelangsungan hidup tertinggi dicapai pada perlakuan E (72,5\%), sedangkan kelangsungan hidup terendah pada perlakuan A. Pada perlakuan A tidak dilakukan penambahan nutrisi dengan viterna, sehingga nutrisi yang terkandung dalam Daphnia kurang optimal untuk memenuhi kebutuhannya. Sedangkan, pada perlakuan E Daphnia telah ditambah nutrisinya dengan viterna. Penambahan viterna pada Daphnia dengan dosis $40 \mathrm{ml}$ dapat mencukupi kebutuhan gizi untuk mempertahankan hidup dan kesehatan ikan. Pada perlakuan E energi metabolisme (ME) yang akan digunakan untuk kelangsungan hidupnya meningkat yaitu $3554,895 \mathrm{Kcal} / \mathrm{kg}$ manjadi $3588,378 \mathrm{Kcal} / \mathrm{kg}$. Pada perlakuan E kelangsungan hidup larva lebih tinggi dibanding dengan perlakuan $\mathrm{B}, \mathrm{C}, \mathrm{D}$ dan $\mathrm{F}$. Pada perlakuan B, C, D dan F, pakan yang diberikan kurang mencukupi gizi untuk memenuhi kebutuhan energi yang digunakan untuk hidup dan berkembang. Energi diperoleh dari makanan yang bernutrisi. Nutrisi makanan yang menghasilkan energi berupa protein, lemak dan karbohidrat (Purwakusuma, 2007). Energi termetabolisme (ME) sebagian dibebaskan dalam bentuk panas dan sebagian untuk sintesis protein, lemak dan karbohidrat. Hasil dari sintesis protein, lemak dan karbohidrat digunakan sebagai energi neto untuk metabolisme dasar (maintenance/pemeliharaan) dan aktivitas, serta sebagian energi disisihkan untuk kecernaan, penyerapan, distribusi dan menyimpan zat tercerna (Linder, 1992).

Energi yang dibutuhkan larva lele berkisar antara 3000-4000 Kcal/kg (De Graff dan Jansen, 1996). Energi yang dihasilkan pada perlakuan E sebesar 3588,378 Kcal/kg. Energi tersebut mencukupi kebutuhan larva untuk maintenance sehingga kelangsungan hidupnya lebih tinggi dibanding perlakuan lain. Sedangkan, perlakuan lain energi yang dihasilkan kurang optimal untuk kelangsungan hidupnya. Energi yang dihasilkan pada perlakuan F adalah 2944,859 Kcal/kg. Pada perlakuan $\mathrm{F}$ kelangsungan hidup larva lele rendah, meskipun pada perlakuan F Daphnia yang diberikan telah diperkaya viterna dengan dosis tinggi $(50 \mathrm{ml} / \mathrm{L})$. Pada penelitian ini pengkayaan dengan viterna dosis tinggi (50 $\mathrm{ml} / \mathrm{L}$ ) ternyata menurunkan kandungan protein Daphnia dan menaikkan kandungan karbohidrat. Kandungan karbohidrat yang berlebih atau tinggi dari yang dibutuhkan dapat menimbulkan kematian ikan karena terjadi pengendapan glikogen dalam hati, dimana hati tidak dapat menyimpan jumlah glikogen yang banyak (Tacon,1987).

Perlakuan B, C dan D kelangsungan hidupnya lebih rendah dibanding perlakuan $\mathrm{E}$. Hal tersebut disebabkan perlakuan $\mathrm{C}$ nilai proteinnya $(62,2483 \%)$ lebih rendah dibandingkan dengan perlakuan E $(63,7979 \%)$, sehingga energi untuk metabolisme dalam tubuh kurang optimal. Perlakuan D protein yang dihasilkan terlalu tinggi yaitu 78,3639\%. Akan tetapi, energi yang dihasilkan sedikit yaitu $2818,209 \mathrm{Kcal} / \mathrm{kg}$, sehingga energi yang ada telah habis digunakan untuk mensintesis protein dalam pembentukan energi untuk pemeliharaan tubuh. Sintesis protein pada tubuh ikan membutuhkan energi yang banyak daripada lemak dan karbohidrat. Linder (1992) menyatakan bahwa energi yang dibutuhkan untuk mensintesis protein sebanyak $30 \%$ dari energi yang ada. Perlakuan B kandungan protein, lemak dan karbohidrat lebih tinggi daripada perlakuan E. Pada perlakuan B diduga larva memanfaatkan protein terlebih dahulu untuk kelangsungan hidupnya, sehingga nutrisi dari lemak dan karbohidrat yang ada tidak dimanfaatkan. Oleh sebab itu, lemak dan karbohidrat tersebut diduga disimpan dalam tubuh. Telah diketahui bahwa karbohidrat tidak dapat disimpan dalam jumlah banyak, sedangkan lemak juga tidak dapat disimpan dalam jumlah banyak karena dapat merusak hati dan menimbulkan kematian dini (Purwakusuma, 2007).

Pada pemeliharaan larva, nutrisi dari
makanan pertama digunakan untuk mempertahankan hidupnya dahulu, selanjutnya digunakan untuk pertumbuhan. Faktor yang mempengaruhi pertumbuhan adalah faktor internal dan faktor eksternal. Faktor internal yaitu faktor yang sukar untuk dikontrol meliputi : keturunan, seks, umur, parasit dan penyakit. Faktor kedua yaitu faktor eksternal yang paling utama mempengaruhi pertumbuhan ikan meliputi : suhu air, DO, $\mathrm{NH}_{3}$ dan ketersediaan makanan (Wahyuningsih dan Barus, 2006). Ketersediaan makanan yang bernutrisi tinggi sangat dibutuhkan larva untuk perkembangan organ tubuh yang masih sederhana menuju 
kesempurnaan (Effendi, 2004). Daphnia yang telah diperkaya dengan viterna, nilai nutrisinya meningkat. Kandungan proteinnya meningkat dari 73,3945 \% (Daphnia tanpa ditambah viterna) menjadi $73,5647 \%$ pada perlakuan penambahan viterna dosis $10 \mathrm{ml} / \mathrm{L}$ air. Pada pertumbuhan larva nutrisi yang diutamakan adalah protein (Hartoyo dan Sukardi, 2007). Daphnia yang telah meningkat kandungan gizinya dapat mempengaruhi pertumbuhan larva lele.

Pada penelitian ini, laju pertumbuhan spesifik yang terbaik dicapai pada perlakuan B $(1,8850 \% \mathrm{~g} / \mathrm{hari})$. Sedangkan, pertumbuhan terendah terdapat pada perlakuan A, hal tersebut disebabkan kandungan gizi berupa protein pada perlakuan B dapat memenuhi kebutuhan larva untuk pertumbuhannya. Protein Daphnia yang terkandung pada perlakuan B meningkat setelah diperkaya yaitu dari $73,3945 \%$ menjadi $73,5647 \%$. Nilai protein tersebut sangat mencukupi kebutuhan larva lele yang berkisar antara 35-40 \% (ADCP, 1983 dalam Gertjam and Johnson, 1996). Perlakuan F dengan dosis pengkaya Daphnia yang tinggi tidak mempengaruhi pertumbuhan yang tinggi. Hal tersebut kemungkinan disebabkan nilai protein yang dihasilkan rendah yaitu $67,8104 \%$ dan nilai karbohidrat yang dihasilkan terlalu tinggi yaitu 20,4679 \%. Kebutuhan karbohidrat untuk larva ikan karnivora sebesar $15 \%$. Pada ikan, karbohidrat yang tinggi dapat menyebabkan pertumbuhan terhambat yang mengakibatkan peningkatan jumlah glikogen pada hati yang dapat menyebabkan kematian pada ikan (Tacon, 1987). Diduga terjadi penimbunan glikogen dalam hati larva karena pergerakannya sedikit.

Pada perlakuan E laju pertumbuhan spesifik lebih rendah dibanding perlakuan B. Hal tersebut dikarenakan protein yang terkandung dalam Daphnia diperlakuan E kurang optimal untuk pertumbuhannya. Protein yang terkandung pada perlakuan E rendah, sehingga energi yang telah dihasilkan habis digunakan untuk kelangsungan hidupnya. Pertumbuhan terhambat bila protein yang terkandung dalam makanan kurang atau rendah (Hartoyo dan Sukardi, 2007). Sedangkan, pada perlakuan D laju pertumbuhan spesifiknya rendah dikarenakan protein yang terkandung dalam Daphnia tinggi, tetapi kandungan lemaknya rendah sehingga untuk menghasilkan energi untuk kelangsungan hidupnya hanya diperoleh dari protein. Oleh sebab itu, protein yang ada kurang optimal untuk pertumbuhan karena sebagian telah digunakan untuk kelangsungan hidup.
Selain itu, lemak yang rendah mempengaruhi pertumbuhan ikan. Lemak berfungsi sebagai sumber energi, mempertinggi penyerapan vitamin-vitamin yang larut dalam lemak, memberi aroma pada pakan dan sebagai daya apung dalam air (Tucher and Robinson, 1991). Tacon (1987) menyatakan bahwa, kebutuhan lemak ikan karnivora adalah $16 \%$. Energi yang dihasilkan lemak digunakan untuk mencari makan, menghindari musuh dan pertumbuhan (Kurnia, 2008). Oleh sebab itu, pada perlakuan D ikan kurang optimal dalam mencari makan. Sedangkan, laju pertumbuhan spesifik pada perlakuan $\mathrm{C}$ rendah dibanding perlakuan B dikarenakan kandungan lemak yang tinggi tetapi kandungan protein rendah.

Kualitas air dalam penelitian berpengaruh karena kualitas air dapat mempengaruhi keberhasilan perlakuan (Mukti dan Rustidja, 2002). DO pada pemeliharaan larva adalah $6 \mathrm{mg} / \mathrm{L}$. Hal tersebut sesuai untuk pemeliharaan lele yaitu minimal $6 \mathrm{mg} / \mathrm{L}$ (Hecht and Uys, 1997). Suhu dalam wadah pemeliharaan larva lele berkisar antara 28-29 ${ }^{\circ} \mathrm{C}$. Suhu tersebut masih sesuai dengan lingkungan hidupnya, dimana pertumbuhan lele terhambat pada suhu kurang dari $20{ }^{\circ} \mathrm{C}$ (Suyanto, 2007). pH selama penelitian berkisar antara 7,5-8. $\mathrm{pH}$ tersebut sesuai untuk pemeliharaan larva lele berkisar antara 6,5-8 (Gunder and Fink, 2008). Kandungan $\mathrm{NH}_{3}$ pada media pemeliharaan larva lele berkisar antara 0,009-0,03 mg/L. Kandungan $\mathrm{NH}_{3}$ tersebut baik untuk pertumbuhan seperti pernyataan Andayani (2005) bahwa $\mathrm{NH}_{3}$ yang terdapat pada media pemeliharaan kurang dari 0,12 $\mathrm{mg} / \mathrm{L}$.

\section{Kesimpulan}

Pemberian viterna pada Daphnia spp. berpengaruh nyata terhadap kelangsungan hidup dan pertumbuhan larva ikan lele dumbo (Clarias gariepinus).

Dosis terbaik pemberian viterna terhadap Daphnia spp. untuk kelangsungan hidup larva ikan lele dumbo (Clarias gariepinus) tertinggi 72,5\% yaitu dosis $40 \mathrm{ml} / \mathrm{L}$ air, sedangkan untuk pertumbuhan tertinggi $1,885 \% \mathrm{~g} / \mathrm{hari}$ yaitu dosis $10 \mathrm{ml} / \mathrm{L}$ air.

Penambahan viterna dalam pakan alami larva lele dumbo dapat digunakan sebagai salah satu alternatif untuk mendapatkan kelangsungan hidup dan pertumbuhan larva lele tanpa pemberian pakan tambahan.

\section{Daftar Pustaka}

Andayani, S. 2005. Manajemen Kualitas Air Untuk Budidaya Perairan. Fakultas 
Perikanan. Universitas Brawijaya. Malang. hal 38-44.

De Graff, G.J. and J. Janssen. 1996. Handbook on The Artificial Reproduction and Pond Rearing of The African Catfish Clarias gariepinus in Sub Saharan Africa. FAO. Fisheries Technical Paper 362. Amsterdam, The Netherlands. p 61-73.

Effendi, I. 2004. Pengantar Akuakultur. Penebar Swadaya. Jakarta. hal 104-156.

Fauzan, M. 2004. Pengaruh Pemberian Suplemen Viterna Pada Pakan Konsentrat Ayam Broiler dalam Dosis yang Berbeda Terhadap Kualitas Daging Ayam Broiler. Skripsi. Fakultas Peternakan. Universitas Jendral Sudirman. Semarang

Gertjam, D. G. and J. Johnson. 1996. Handbook on The Artificial Reproduction and Pond Rearing of The African Catfish (Clarias gariepinus) in Sub Saharan Africa. Fisheries Technical Paper. Nevisco Foundation. Amsterdam. Netherland. 92 pp.

Gunder, H. and W. Fink. 2008. Clarias gariepinus. North African Catfish. Museum of Zoology. Animal Diversity Web. University of Michigan. http://animaldiversity.ummz.umich.edu/s ite/accounts/information/Clarias_gariepi nus.html. 3 hal.

Hartoyo dan P. Sukardi. 2007. Alternatif Pakan Ternak Ikan. Pusat Ahli Teknologi dan Kemitraan (Pattra). Lembaga Penelitian Universitas Jenderal Soedirman. Purwokerto. http://www.IndoPosOnline.co.id. 4 hal.

Hecht and Uys. 1997. The Biology and Culture of African Catfish (Clarias gariepinus). South African Journal of Science. Africa. 6 hal.

Khairuman dan K. Amri. 2002. Budidaya Lele Dumbo Secara Intensif. Agromedia Pustaka. Jakarta. 77 hal.

Kurnia, A. 2008. Dicari Pakan Ikan Berkualitas, Murah dan Ramah Lingkungan. Artikel Iptek. http://www.beritaiptek.com. 3 hal.

Kusriningrum. 1989. Dasar-dasar Perancangan Percobaan dan Rancangan Acak Lengkap. Universitas Airlangga. Surabaya. 143 hal.

Lavens, P. and P. Sorgeloos. 1996. Manual on the Production and Use of Live Food for Aquaculture. FAO Fisheries Technical Paper. Laboratory of Aquaculture and Artemia Reference Center University of Ghent. Belgium. 4 hal.
Linder, M. C. 1992. Biokimia Nutrisi dan Metabolisme Dengan Pemakaian Secara Klinis. Universitas Indonesia Press. Jakarta. hal 347-365.

Maya. 2006. Pembenihan Ikan Lele Dumbo. Jakarta. http://www.lycos.com. 3 hal.

Mukti, A.T. dan Rustidja. 2002. Teknologi Pembenihan. Pelatihan Teknologi Kelautan Diktat Propinsi Jawa Timur. Surabaya. 18 hal.

Mukti, A.T., W. H. Satyantini dan M. Arief. 2004a. Penuntun Praktikum Rekayasa Akuakulture. Universitas Airlangga. Surabaya.

Purwakusuma, W. 2007. Kebutuhan Nutrisi Ikan. http://www.ofish/KebutuhanNutrisilkan. 2 hal.

Schumann, K. 2006. Daphnia. FAQ. Discus Article. Discus Breeding Website. http ://www.KS@Lilly.com. 2 hal.

Sutanmuda. 2007. Budidaya Ikan Lele. Proyek Pengembangan Ekonomi Masyarakat Pedesaan, BAPPENAS. Jakarta. 20 hal

Suyanto, S.R. 2007. Budidaya Ikan Lele. Edisi Revisi. Penebar Swadaya. Jakarta. 92 hal.

Sahoo S.K., S.S. Giri and A.K. Sahu. 2004. Effect of Stocking Size of Clarias batrachus Fry on Growth and Survival During Fingerling Hatchery Production. Central Institute of Freshwater Aquaculture. Kausalyaganga, Bhubaneswar-751 002. Orissa. India. 5 pp.

Tacon, A. G. J. 1987. The Nutrition and Feeding of Farmed fish and Shrimp. Traning Manual 1. The Essential Nutrients. Food and Agriculture Organization of The United Nations. Brasilia. Brasil. 94 hal.

Tucker, C.S. and E.H. Robinson. 1991. Channel Catfish Farming Handbook. An Avi Book. New York. 454 pp

Wahyu, P. 2007. Daphnia. Media Informasi Ikan Hias. Jakarta. http://www.ofish.com. 15 hal.

Wahyuningsih, H. dan T.A. Barus. 2006. Hibah Kompetensikonten Mata Kuliah ELearning. Departemen Biologi. Fakultas Matematika dan Ilmu Pengetahuan Alam. Universitas Sumatera Utara. 119 hal.

Wikipedia. 2007. Daphnia. The Free Encyclopedia. http://en.wikipedia.org. 4 hal.

Wisnu. 2007. Pakan Tambahan Ikan. Yogyakarta.http://www.wisnoe@mail.ac .id. 2 hal. 